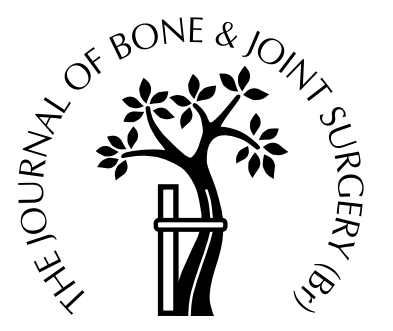

\title{
BMP-4 of Xenopus laevis stimulates differentiation of human primary osteoblast-like cells
}

\author{
U. Mayr-Wohlfart, S. Kessler, W. Puhl, K. P. Günther, \\ W. Knöchel \\ From the University of Ulm, Germany
}

Qince bone morphogenetic proteins (BMPs) are Ohighly homologous, we investigated the hypothesis that recombinant BMP-4 of the genome of Xenopus laevis (rxBMP-4) may influence the proliferation or differentiation of human primary osteoblast-like cells (HPOC), as occurs with recombinant human BMP (rhBMP-2).

HPOC were incubated in the presence of either rxBMP-4, rhBMP-2 or basic fibroblast growth factor (rh-bFGF). The last two were used as positive controls and are known to induce differentiation or proliferation of $\mathrm{HPOC}$, respectively.

rxBMP-4 $(50 \mathrm{ng} / \mathrm{ml}$ and $100 \mathrm{ng} / \mathrm{ml})$ induced a differentiation of HPOC to almost the same extent as rhBMP-2, whereas the addition of rh-bFGF, applied in the same concentration, failed to have any influence on cell differentiation. rh-bFGF however, provoked an increase in cell proliferation of up to $150 \%$ when compared with non-stimulated HPOC, while rhBMP-2 and rxBMP-4 had no such effect.

Our results indicate an equipotent effect of rhBMP-2 and rxBMP-4 obtained from Xenopus laevis on the differentiation and proliferation of human primary osteoblast-like cells.

J Bone Joint Surg [Br] 2001;83-B:144-7.

Received 21 May 1999; Accepted after revision 29 October 1999

Bone morphogenetic proteins (BMPs) are cytokines originally identified as factors extractable from bone ${ }^{1}$ which induce the formation of ectopic bone at non-skeletal sites of implantation. $^{2-5}$

U. Mayr-Wohlfart, PhD, Research Assistant

S. Kessler, MD, Consultant Orthopaedic Surgeon

W. Puhl, MD, Professor of Orthopaedics

K. P. Günther, MD, Assistant Professor of Orthopaedics

Department of Orthopaedic Surgery, (RKU), University of Ulm, Oberer Eselsberg 45, 89081 Ulm, Germany.

W. Knöchel, PhD, Professor of Biochemistry

Department of Biochemistry, University of Ulm, 89081 Ulm, Germany.

Correspondence should be sent to Dr U. Mayr-Wohlfart.

(C)2001 British Editorial Society of Bone and Joint Surgery 0301-620X/01/110219\$2.00
After cloning the first four cDNAs, Wozney et $\mathrm{al}^{6}$ demonstrated that with the exception of BMP-1, BMPs belong to the transforming growth factor- $\beta$ (TGF- $\beta$ ) superfamily. BMP-2 and BMP-4, previously BMP-2A and BMP$2 \mathrm{~B}$, are quite closely related and form one group ${ }^{5,7}$ within this superfamily. BMP-2 has been shown to induce bone formation de novo and bone repair in vivo. ${ }^{8}$ In vitro experiments, using recombinant human BMP-2 (rhBMP-2) have been carried out to explore the effects of BMPs on the differentiation of osteoblasts and the formation of bone. $^{9-12}$

A sequence analysis of the amino-acid composition of human BMP-4 and BMP-4 derived from Xenopus laevis (rxBMP-4) has revealed a close relationship between both proteins, especially in the mature part of the protein. ${ }^{13}$ To the best of our knowledge, nothing is known about the physiological effects of rxBMP-4 on the process of differentiation and repair of human bones, but it is known to be an inducer of mesoderm formation during the early stage of development of the Xenopus embryo ${ }^{13}$ and it provokes cell differentiation of the osteoblastic mouse cell line MC3T3E1. ${ }^{14}$

Because of the high conservation and the similarity of the protein, the question arose as to whether rxBMP-4 like rhBMP-2 is able to promote the differentiation of human osteoblasts. To test this hypothesis, we examined the effects of rxBMP-4, rhBMP-2 and recombinant human fibroblast growth factor (rh-bFGF). In contrast to BMPs, bFGF, which is also synthesised in osteoblasts, seems to be a bone-regulating factor since it enhances the proliferation of osteoblasts in vitro ${ }^{15,16}$ with an inhibitory effect on their differentiation. ${ }^{17}$

\section{Materials and Methods}

Cell culture. Cultures of osteoblasts were established according to the method described by Robey and Termine. ${ }^{18}$ Fragments of cancellous bone were obtained during routine hip and knee replacements from four men and two women aged between 34 and 79 years. The fragments were dissected, minced, and rinsed several times with physiological saline solution to remove blood components. For collagenase digestion, the bone chips were incubated in serum-free Dulbecco's modification of Eagle's minimum 
essential medium (DMEM) containing $0.5 \%$ of crude collagenase (type IV; Sigma Chemical Company, St Louis, Missouri) at $37^{\circ} \mathrm{C}$ with rotation for two hours. The remaining collagenase-treated bone chips were washed once with serum-containing medium to inhibit collagenase and plated in six-well plates. The cells were incubated with DMEM culture medium which was depleted for $\mathrm{Ca}^{2+}$ and supplemented with $10 \%(\mathrm{v} / \mathrm{v})$ heat-inactivated fetal calf serum (FCS), $2 \mathrm{mM}$ L-glutamine, $100 \mathrm{U} / \mathrm{ml}$ of streptomycin/penicillin, 1.0\% amphotericin B (all compounds from Biochrom KG, Berlin, Germany) and $0.08 \%$ certomycin 50 (Essex Pharma GmbH, München, Germany). The cell cultures were incubated at $37^{\circ} \mathrm{C}$ in $5 \% \mathrm{CO}_{2}$ and saturated humidity. The culture medium was changed twice a week.

A confluent monolayer with primary human osteoblastlike cells was detected after about four to five weeks. Cells were subcultured by $0.05 \%(\mathrm{w} / \mathrm{v})$ trypsin and $0.02 \%(\mathrm{w} / \mathrm{v})$ EDTA. Experiments were performed only in one of the first three cell passages as well as in the stage of cell maturation.

This technique of cell isolation maintains the osteoblastic phenotype as deduced from the synthesis of osteocalcin and type-I procollagen, and von Kossa staining. ${ }^{19,20}$

Growth factors. The cells were stimulated by three different growth factors. rh-bFGF was purchased from TEBU GmbH (Frankfurt, Germany), rhBMP-2 was provided by the Theodor-Boveri Institute of the University of Würzburg, Germany ${ }^{21}$ and rxBMP-4 was produced in a bacterial expression system as follows. The mature part of the protein (rxBMP-4) fused to a His-tag was expressed in $E$. coli. The protein was purified by $\mathrm{Ni}^{2+}$-agarose-column chromatography and refolded by dialysis. The amount of the isolated rxBMP-4 was assayed on a Coomassie-stained polyacrylamide gel.

Measurement of proliferation. Osteoblastic cells were plated at a density of 5000 cells/well in 96-well flatbottomed Nunclon microwell plates (Nunc, Roskilde, Denmark). The cells were grown in DMEM culture medium, composed as described above, but supplemented with $1.8 \mathrm{mM} \mathrm{Ca}^{2+}$. Cells were allowed to adhere for 24 hours. Thereafter, serum-free DMEM culture medium, containing two different concentrations of the growth factors $(50 \mathrm{ng} /$ $\mathrm{ml}$ and $100 \mathrm{ng} / \mathrm{ml}$ ), was added and the plates were incubated for an additional 72 hours. The rates of proliferation were estimated by colorimetric MTT (3-(4,5-dimethylthiazol-2-yl)-2,5-diphenyltetrazolium bromide) assay. ${ }^{22}$ The assay principle is based on a reduction of MTT (Sigma Chemical Co) by mitochondrial dehydrogenases of viable cells. The MTT reaction product, a blue formazan derivative, was measured photometrically at $550 \mathrm{~nm}$. Ten microlitres of MTT stock solution $(5 \mathrm{mg} / \mathrm{ml})$ were added to each well and incubated at $37^{\circ} \mathrm{C}$ for four hours. The microwell plates were centrifuged at $4000 \times g$ for ten minutes and the supernatant was removed. Dimethylsulphoxide was added to each well to solubilise the formazan crystals. Afterwards, microtitre plates were placed on a plate shaker for five minutes and the absorbence was monitored at $550 \mathrm{~nm}$ using a microtitre plate reader.

Measurement of cell differentiation. The extent of cell differentiation was judged from the increase in activity of the enzyme alkaline phosphatase (ALP). ${ }^{23}$ Osteoblastic cells were plated at a density of 100000 cells/well in 12-well Nunclon microwell plates (Nunc), stimulated by growth factors and cultured for 72 hours as described above. After washing the cells, a lysis buffer containing $0.1 \%$ (v/v) Triton X-100, $1 \mathrm{mM} \mathrm{MgCl} 2,0.1 \mathrm{mM} \mathrm{ZnCl}_{2}$ and $20 \mathrm{mM}$ Tris (Merck KG, Darmstadt, Germany), pH 10, was added and the cells were frozen at $-80^{\circ} \mathrm{C}$ and stored overnight. The activity of ALP was determined by a diagnostic kit according to the instructions of the supplier (Boehringer Mannheim GmbH, Mannheim, Germany). For each assay, $100 \mu \mathrm{l}$ of cell lysate were incubated with $1 \mathrm{ml}$ of a p-nitrophenyl phosphate solution $(10 \mathrm{mM})$. The activity of ALP was monitored photometrically $(405 \mathrm{~nm})$ by the production of p-nitrophenol.

Identification of the osteoblastic phenotype. The detection of osteocalcin, type-1 procollagen and cell mineralisation was used to verify the phenotype of the cells. ${ }^{19,20}$ The amount of osteocalcin and type-1 procollagen secreted into the culture medium was measured photometrically using commercially available kits (Novocalcin and Prolagen-C; DPA Biermann GmbH, Bad Nauheim, Germany). Cell mineralisation of fixed cell layers was determined microscopically by a modified von Kossa staining technique. ${ }^{24}$

Statistical analysis. All measurements were performed at least in triplicate. Unless otherwise stated, the results are shown as the mean \pm standard deviation (SD) expressed as the percentage of the control. Single-factor analysis of variance (ANOVA) was used to assess the statistical significance of data. Dunnet's method was used for multiple comparison tests. Differences in means were considered to be significant if $\mathrm{p} \leq 0.05$.

\section{Results}

The proliferation of human primary osteoblast-like cells (HPOC), derived from the bone material of six donors, differed with respect to the time period after which a state of confluence was attained. This was reached between three and six weeks after seeding of the bone fragments (mean 35 \pm 6.3 days). Although the age of the donors varied considerably (mean $62.8 \pm 21.3$ years; range 34 to 79 ), there was no correlation between the age and the rate of proliferation $(\mathrm{p}=0.042)$.

The cell samples of all six donors showed characteristic features of an osteoblastic phenotype. After incubation for four days the cells synthesised measurable levels of osteocalcin (19 to $23.5 \mathrm{ng} / 10^{6}$ cells) when cultured in the presence of $10^{-6} \mathrm{M} 1,25-(\mathrm{OH})_{2}$ vitaminD $\mathrm{D}_{3}$, and type-I procollagen ( 15.0 to $23.2 \mu \mathrm{g} / 10^{6}$ cells). These results correlated with the mineralisation of the cells seen microscopically after von Kossa staining (data not shown). 


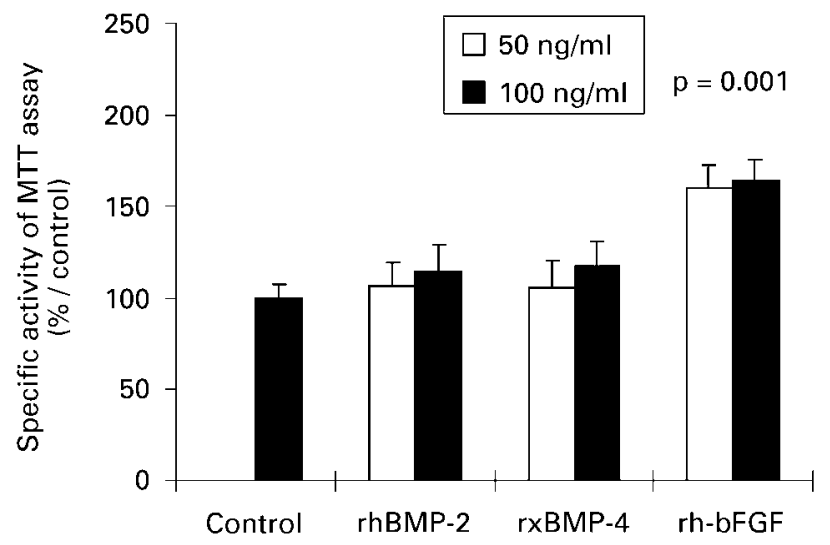

Fig. 1

Mean ( \pm SD) specific activity of the MTT assay (\%/control) for rhBMP-2, rxBMP-4 (50 and $100 \mathrm{ng} / \mathrm{ml})$ and rh-bFGF (see text).

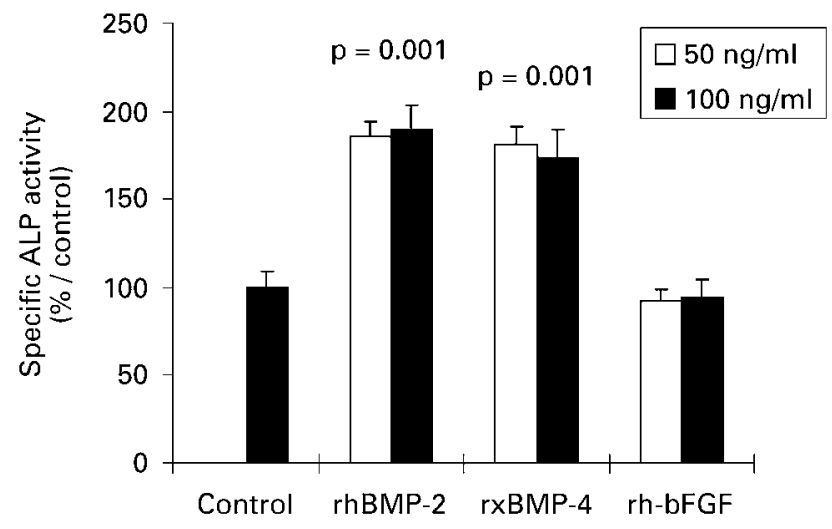

Fig. 2

Mean $( \pm \mathrm{SD})$ specific activity for ALP for rhBMP-2, rxBMP-4 (50 and $100 \mathrm{ng} / \mathrm{ml}$ ) and rh-bFGF (see text).

After an incubation period of 72 hours the addition of rhbFGF $(50 \mathrm{ng} / \mathrm{ml}$ and $100 \mathrm{ng} / \mathrm{ml})$ induced a significant increase in the rate of proliferation of the cell cultures by about $50 \%$ (Fig. 1). rhBMP-2 and rxBMP-4, however, had no effect.

The ALP activity of untreated cells was $7.2 \pm 0.7 \mathrm{U} / \mathrm{ml}$. As shown in Figure 2, both BMPs provoked cell differentiation as judged by the increase in ALP activity by almost the same extent $(78 \%)$ compared with untreated cells. No difference in efficacy was observed between human BMP and Xenopus BMP (Fig. 2). The addition of rh-bFGF had no effect on cell differentiation (Fig. 2).

\section{Discussion}

Our findings showed that rh-bFGF stimulated the proliferation of HPOC but failed to provoke cell differentiation. By contrast, rhBMP-2 and rxBMP-4 did not affect cell proliferation but induced a differentiation of HPOC to almost the same extent. These findings are based on two independent parameters, namely the rate of proliferation and the activity of ALP, which is a well-accepted marker of osteogenesis in these cultures. 23

This suggests that either the cells seem to have receptors for BMP-2 and BMP-4 or that both BMPs bind with almost the same affinity to the same receptor. This observation agrees with the results of radioligand binding assays published by Yamaji et al. ${ }^{25}$ They showed that rhBMP-2 and rhBMP-4 bind with similar affinities to the same CFK-43a protein, which was thought to be a serine/threonine kinase receptor of rhBMP-2 and rhBMP-4. This assumption was confirmed by several authors who showed that rhBMP-2 and rhBMP-4 bind to the same receptor type classified as BMPR-II. $^{26}$

According to our data, rxBMP-4 was as equally effective as rhBMP-2, suggesting that human BMP-4 and Xenopus BMP-4 bind to the same receptor, which is presumably BMPR-II. This idea is consistent with the high degree of amino-acid homology $(86 \%$ in the mature part of the protein) observed for rhBMP-4 and rhBMP-2.

rxBMP-4 failed to stimulate proliferation of HPOC and behaved like rhBMP-2. To exclude a false-negative result, rh-bFGF was used as a positive control to stimulate cell proliferation. ${ }^{15,16}$ As expected, 50 to $100 \mathrm{ng} / \mathrm{ml}$ of $\mathrm{rh}-\mathrm{bFGF}$ enhanced cell proliferation by about $80 \%$ of the control value. This result is consistent with previous studies which showed an antagonistic interaction between the signalling system of FGF and BMP in a model of limb outgrowth. Niswander and Martin ${ }^{27}$ proved that FGF-4 stimulated proliferation of mesenchyme in the early mouse limb bud, whereas rhBMP-2 inhibited limb growth. Zheng et $\mathrm{al}^{28}$ reported, however, that rhBMP-2 stimulated cell proliferation in a human osteoblast-like cell line (HOB1T). This discrepancy in the action of rxBMP-4 on HOB1T and HPOC may be due to the difference in origin of both cell types. Zheng et $\mathrm{al}^{28}$ used a permanent cell line established by transfection with SV40 large T antigen, whereas we used primary human osteoblast-like cells.

Considering the concentration dependency of the BMP action, we have shown that in our in vitro model HPOC differentiation was already induced at a concentration of BMP of 50 to $100 \mathrm{ng} / \mathrm{ml}$. This effective range of concentration corresponds to data published by Hughes et al. ${ }^{29}$ They induced the formation of bone nodules by rhBMP-2 and rhBMP-4 which were maximally effective in a range of 25 to $50 \mathrm{ng} / \mathrm{ml}$ of BMP. Similar results were obtained by Fromigué, Marie and Lomri ${ }^{30}$ who induced maximal ALP activity in human bone-marrow stromal cells with $100 \mathrm{ng} /$ $\mathrm{ml}$ of rhBMP-2 and Kawasaki et $\mathrm{al}^{12}$ who stimulated HPOC with 50 to $250 \mathrm{ng} / \mathrm{ml}$. At the same concentration, Niswander and Martin ${ }^{27}$ provoked a hindlimb outgrowth by application of rhBMP-2 to the biological assay of limb bud induction in mice.

Our data therefore indicate a similar action by human BMP-2 and Xenopus BMP-4 on the differentiation of human primary osteoblast-like cells at least with respect to the induction of ALP activity and proliferation. 
We gratefully thank Professor L. Claes, Dr A. Ignatius and Dr J. Högel for their support in performing this investigation.

No benefits in any form have been received or will be received from a commercial party related directly or indirectly to the subject of this article.

\section{References}

1. Urist MR. Bone: formation by autoinduction. Science 1965;150: 893-9.

2. Sampath TK, Reddi AH. Dissociative extraction and reconstitution of extracellular matrix components involved in local bone differentiation. Proc Natl Acad Sci USA 1981;78:7599-603.

3. Urist MR, Lietze A, Mizutani $\mathbf{H}$, et al. A bovine low molecular weight bone morphogenetic protein (BMP) fraction. Clin Orthop 1982;162:219-32.

4. Wozney JM, Rosen V. Bone morphogenetic protein and bone morphogenetic protein gene family in bone formation and repair. Clin Orthop 1998;346:26-37.

5. Reddi AH. Role of morphogenetic proteins in skeletal tissue engineering and regeneration. Nat Biotechnol 1998;16:247-52.

6. Wozney JM, Rosen V, Celeste AJ, et al. Novel regulators of bone formation: molecular clones and activities. Science 1988;242:1528-34.

7. Wozney JM, Rosen V, Byrne M, et al. Growth factors influencing bone development. J Cell Sci Suppl 1990;13:149-56.

8. Toriumi DM, Kotler HS, Luxenberg DP, Holtrop ME, Wang EA. Mandibular reconstruction with a recombinant bone-inducing factor: functional, histologic and biomechanical evaluation. Arch Otolaryngol Head Neck Surg 1991;117:1101-12.

9. Takuwa Y, Ohse C, Wang EA, Wozney JM, Yamashita K. Bone morphogenetic protein-2 stimulates alkaline phosphatase activity and collagen synthesis in cultured osteoblastic cells, MC3T3-E1. Biochem Biophys Res Commun 1991;174:96-101.

10. Thies RS, Bauduy M, Ashton BA, et al. Recombinant human bone morphogenetic protein-2 induces osteoblastic differentiation in W20-17 stromal cells. Endocrinology 1992;130:1318-24.

11. Rickard DJ, Sullivan TA, Shenker BJ, Leboy PS, Kazhdan I. Induction of rapid osteoblast differentiation in rat bone marrow stromal cell cultures by dexamethasone and BMP-2. Dev Biol 1994;161:218-28.

12. Kawasaki K, Aihara M, Honmo J, et al. Effects of recombinant human bone morphogenetic protein-2 on differentiation of cells isolated from human bone, muscle and skin. Bone 1998;23:223-31.

13. Köster M, Plessow S, Clement JH, et al. Bone morphogenetic protein 4 (BMP-4), a member of the TGF- $\beta$ family, in early embryos of Xenopus laevis: analysis of mesoderm-inducing activity. Mech Dev 1991;33:191-9.

14. Nishimatsu S, Suzuki A, Shoda A, Murakami K, Ueno N. Genes for bone morphogenetic proteins are differentially transcribed in early amphibian embryos. Biochem Biophys Res Commun 1992;186:1487-95
15. Globus RK, Patterson-Buckendahl P, Gospodarowicz D. Regulation of bovine bone cell proliferation by fibroblast growth factor and transforming growth factor- $\beta$. Endocrinology 1988;123:98-105.

16. Canalis E, Centrella M, McCarthy T. Effects of basic fibroblast growth factor on bone formation in vitro. $J$ Clin Invest 1988;81:1572-7.

17. Rodan SB, Wesolowski G, Thomas KA, Yoon K, Rodan GA. Effects of acidic and basic fibroblast growth factors on osteoblastic cells. Connect Tissue Res 1989;20:283-8.

18. Robey PG, Termine JD. Human bone cells in vitro. Calcif Tissue Int 1985;37:453-60.

19. Beresford JN, Gallagher JA, Poser JW, Russell RG. Production of osteocalcin by human bone cells in vitro: effects of $1,25(\mathrm{OH})_{2} \mathrm{D}_{3}, 24,25(\mathrm{OH})_{2} \mathrm{D}_{3}$, parathyroid hormone and glucocorticoids. Metab Bone Dis Relat Res 1984;5:229-34.

20. Jonsson KB, Ljunghall S, Karlstrom O, et al. Insulin-like growth factor 1 enhances the formation of type I collagen in hydrocortisonetreated human osteoblasts. Biosci Rep 1993;13:297-302.

21. Kübler NR, Reuther JF, Faller G, et al. Inductive properties of recombinant human BMP-2 produced in a bacterial expression system. Int J Oral Maxillofac Surg 1998;27:305-9.

22. Mosmann T. Rapid colorimetric assay for cellular growth and survival: application to proliferation and cytotoxicity assays. J Immunol Methods 1983;65:55-63.

23. Kasperk CH, Wergedal JE, Mohan S, et al. Interactions of growth factors present in bone matrix with bone cells: effects on DNA synthesis and alkaline phosphtase. Growth Factors 1990;3:147-58.

24. Sampath KT, Maliakal JC, Hauschka PV, et al. Recombinant human osteogenic protein-1 (hOP-1) induces new bone formation in vivo with a specific activity comparable with natural bovine osteogenic protein and stimulates osteoblast proliferation and differentiation in vitro. J Biol Chem 1992;267:20352-62.

25. Yamaji N, Celeste AJ, Thies RS, et al. A mammalian serine/threonine kinase receptor specifically binds BMP-2 and BMP4. Biochem Biophys Res Commun 1994;205:1944-51.

26. Massagué J, Weis-Garcia F. Serine/threonine kinase receptors: mediators of transforming growth factor beta family signals. Cancer Surv 1996;27:41-64.

27. Niswander L, Martin GR. FGF-4 and BMP-2 have opposite effects on limb growth. Nature 1993;361:68-71.

28. Zheng MH, Wood DJ, Wysocki S, Papadimitriou JM, Wang EA. Recombinant human bone morphogenetic protein-2 enhances expression of interleukin- 6 and transforming growth factor-beta 1 genes in normal human osteoblast-like cells. J Cell Physiol 1994;159:76-82.

29. Hughes FJ, Collyer J, Stanfield M, Goodman SA. The effects of bone morphogenetic protein-2, -4 and -6 on differentiation of rat osteoblast cells in vitro. Endocrinology 1995;136:2671-7.

30. Fromigue O, Marie PJ, Lomri A. Bone morphogenetic protein-2 and transforming growth factor- $\beta_{2}$ interact to modulate human bone marrow stromal cell proliferation and differentiation. $J$ Cell Biochem 1998;68:411-26. 